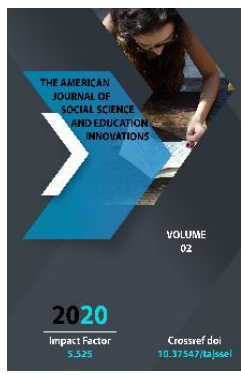

\title{
Review Of Some Classifications Of Words Denoting Nationally Specific Realities
}

\section{Mohira Umarova}

Phd Student, Tashkent State University Of Oriental Studies, Tashkent, Uzbekistan

\section{ABSTRACT}

The object of our research is the national specific realities encountered in literary and artistic works. This article defines the term "reality" as the functionality of words in this particular category as components necessary to convey the national identity of texts in different languages. The article discusses different approaches aimed at defining the concept of reality in translation studies and related linguistics. The definition of the concept given in various dictionaries is given then a comparative analysis of the interpretation of the term in the works of linguists is carried out.

Linguists started talking about realities as carriers of national originality in the early $505 \mathrm{XX}$ century. From the very beginning, there were significant differences among scientists on the definition of the concept of reality they were designated as "barbarism", "exoticism", "exotic vocabulary", "nonequivalent vocabulary", etc.

In the annotated study, the classifications of realities proposed by G.D. Tomakhin, E.M. Vereshchagin and V.G. Kostomarov, L.S. Barkhudarov, V.S. Vinogradov, S Vlakhov and S. Florin. The most advanced authors consider the classification of truths given by the Bulgarian scholars S. Vlakhov and S. Florin. According to the authors of the article, this classification allows you to highlight and identify a large number of truths in the translated language.

\section{KEYWORDS}

Translation, reality, exoticism, exotic vocabulary, non-equivalent vocabulary, national flavor. 


\section{INTRODUCTION}

When any work of art, regardless of its type or genre, is created on a specific national basis, it reflects national life and specific national issues. The transfer of national and cultural flavor when translating a work is always a difficult task for a translator. Often a translator finds himself in a situation where the native speaker of the language into which the literary work is being translated is not familiar with the designations of the things shown in the original work and the images that were associated with them. The object of our research is artistic translation, which is a relatively independent unit relative to the original text. The reader of the translated work perceives it as an independent work that has been transferred by the translator to another culture and has become part of the literary and social reality of the native speakers of the translated language.

When conveying realities, the translator is faced with the following problem, identified by the Bulgarian researchers S. Vlakhov and S. Florin, who believed that "the translation of realities is part of a large and important problem of conveying national and historical identity, which must go back to the very origin the theory of translation as an independent discipline" [1. 5-6].The reader of the translated text should easily understand the text and, at the same time, feel the national flavor that was created by this reality.

The main task of a literary text translator is to create a work of artistic value equal to the original. The works of art have a lot of nonequivalent vocabulary that serves to create a national color, but in fact show semantic shadows that create a linguistic picture of the world of a particular nation, so the main task of the translator is to preserve the linguistic picture of the original work is to recreate the text.

\section{MAIN PART}

In 1952, L.N Sobolev's work "A Guide to Translation from Russian into French" was published, in which the term "reality" was used for the first time (from Lat. Realis, -e "material, real"). L.N Sobolev the term "reality" means everyday and specifically national words and phrases that have no equivalents in everyday life and, therefore, in the language of other countries, as well as "words from national life that are not in other languages, because these objects and there are no phenomena in other countries" [281]

In the "Dictionary of linguistic terms" O.S. Akhmanova describes reality as "any object of material culture," "in classical grammar, various factors studied by external linguistics, such as the state structure of the country, the history and culture of a given people, linguistic contacts of speakers of this language, etc. from the point of view of their reflection in a given language"[3. 381]. In the Brief Literary Encyclopedia, the following definition is given: "Reality ... is an object, concept, phenomenon characteristic of the history, culture, way of life, way of life of this or that nation, country, not found among other nations; R. is also a word denoting such an object, concept, phenomenon; also a phrase"[4. 227]. In the “Explanatory Dictionary of Foreign Words" L.P Krysin the following definition is given: "Reality is an object, thing, phenomenon that exists in reality" [5. 654]. In the "Dictionary of Foreign Words" by N. G. Komlev, the term is interpreted as follows: "Realia (late Latin realis - real, true) - 1) subject; really existing, concrete thing; 2) realities - objective facts as a historical background of a literary or other 
description; in the methodology of teaching foreign languages - ethnic or national characteristics that are reflected in the given language, but not translated into others (or translated only descriptively)[6.498].

The former include V.S. Vinogradov, A.V. Fedorov, G.D. Tomakhin, M.L. Vaysburg, A.D. Schweitser and other researchers. Realities as a word denoting an unfamiliar concept from the translated language were considered by L.N. Sobolev, V.I. Rossels, A.E. Suprun, L.S. Barkhudarov, Ya.I. Retsker.

V.S. Vinogradov calls realities all the specific facts of the history and state structure of a national community, the features of its geographical environment, typical household items of the past and present, ethnographic and folklore concepts, referring them to the class of non-equivalent vocabulary [7. 37].

A.V. Fedorov speaks of words "denoting the realities of social life and material life", that is, such words that mean "a local phenomenon that has no correspondence in the life and concepts of another people" [8.175].

G.D. Tomakhin formulated the following definition of the term: "Realities are the names of objects of material culture inherent only to certain nations and peoples, historical facts, state institutions, the names of national and folklore heroes, mythological creatures, etc[9.5].

According to M.L. Weissburd, the realities include "events of the country's social and cultural life, public organizations and institutions, customs and traditions, household items, geographical points, works of art and literature, names of historical figures, public figures, scientists, writers, composers, artists, popular athletes, characters of works of art, natural phenomena, as well as many disparate factors that cannot be classified"[10.98]

A.D.Shveitser defines realities as "objects or phenomena associated with history, culture, economy and everyday life" [11. 250] [Schweitzer, 1973, p. 250]. L.N. Sobolev believes that realities are "everyday and specific national words and phrases that have no equivalents in everyday life, and, therefore, in the languages of other countries." S. Florin and S. Vlakhov call realities "words ... that name objects characteristic of the life (everyday life, culture, social and historical development) of one people and alien to another, expressing national and (or) historical flavor, not having as a rule, exact matches in another language and requiring a special approach in translation." Just like L.N. Sobolev, S. Florin and S. Vlakhov understand reality both as an object and as a word [Vlakhov, Florin, 1980, p. 7].

VI. Rossels sees in reality "foreign words that denote concepts, objects, phenomena that do not exist in the everyday life of the people into whose language the works are translated" [12. 169].

A.E. Suprun in his article, considering the realities from the point of view of linguistics, calls them "exotic" vocabulary: "In geographical and historical descriptions, where there is a need to designate the corresponding realities, the use of exotic vocabulary is natural, and here its role approaches with the role of terminological vocabulary" [13.50-54].

L.S. Barhudarov in the monograph "Language and Translation" gives the following definition of realities - these are "... words denoting objects, concepts and situations that do not 
exist in the practical experience of people speaking another language" [14.95].

Bulgarian researchers S. Vlakhov and S. Florin define realities as a special category of means of expression, which include words and phrases that name objects that are characteristic of the life, everyday life, culture and history of one people and alien to another [1. 6].

Ya.I. Retsker speaks about "non-equivalent vocabulary", which is "designation of realities characteristic of the country of the I.Ya [source language] and alien to another language and other reality" [Retsker, 1974, p. 58]

In our study, we want to consider the classifications of realities proposed by G.D. Tomakhin, E.M. Vereshchagin and V.G. Kostomarov, L.S. Barkhudarov, V.S. Vinogradov, S. Vlakhov and S. Florin.

G.D Tomakhin, highlighting modern and historical realities, gives them the following definition: "historicisms are words denoting dead realities, and neologisms are words denoting realities that have arisen in a given period." [9. 10] Considering American realities, he distinguishes three large groups:

1. onomastic realities, which include geographic realities (toponyms); anthroponyms - names of historical figures, public figures, scientists, writers, artists, characters of fiction and folklore; titles of works of literature and art, historical facts and events in the life of the country, names of state and public institutions, etc 15. 7-13]

2. realities denoted by appellative (referring to appeal, which is appeal) vocabulary: geographic terms; some words related to the state structure, social and political life of the country, jurisprudence, military affairs, art, traditions and customs, everyday life, etc ;

3. Realities of the aphoristic level - quotes, catchwords and expressions. "Understanding the meaning of the quote itself is not difficult, but its meaning and the meaning of the whole statement cannot be understood if the context from which it is taken is not known." [9].

E.M. Vereshchagin and V.G. Kostomarov characterize realities as vocabulary containing background information[16. 28]. Taking the material of the Russian language as a basis, they identified seven groups of words that have national-cultural semantics: Sovietisms, words of a new way of life, words of traditional life, historicism, phraseological units and words from folklore and words of non-Russian origin.

L.S. Barhudarov presents realities as a separate category of non-equivalent vocabulary and distinguishes the following categories: proper names, geographical names, names of institutions, organizations, newspapers, etc; realities - words denoting objects, concepts and situations that do not exist in the practical experience of people speaking another language; random lacunas units of the vocabulary of one of the languages, which for some reason do not correspond in the lexical composition of another language [14.53].

V.S. Vinogradov believes that realities are of a national nature and are among the nonequivalent vocabulary and he divides all words-realities into 6 groups, highlighting: [7. 54-73] 
1. Vocabulary that names everyday realities to which they relate:

- $\quad$ Dwelling, property;

- $\quad$ Clothes, headwear;

- $\quad$ Food, drinks;

- $\quad$ Types of work and occupation;

- $\quad$ Banknotes, units of measure;

- Musical instruments, folk dances and songs, performers;

- $\quad$ Folk holidays, games;

- Appeals;

2. The vocabulary that names ethnographic and mythological realities, which include:

- Ethnic and social communities and their representatives;

- Deities, fairy creatures, legendary places.

3. Vocabulary that names the realities of the natural world, which include animals, plants and landscape;

4. Vocabulary that names the realities of the state and administrative structure and public life (current and historical), which include:

- Administrative units and state institutions;

- $\quad$ Public organizations, parties, etc., their functionaries and participants;

- Industrial and agricultural enterprises, trade establishments;

- Major military and police units and ranks;

- $\quad$ Civil positions and professions, titles.

5. The vocabulary that names onomastic realities, which include:

anthroponyms, place names, names of literary heroes, names of companies, museums, theaters, restaurants, shops, beaches, airports, etc.

6. Vocabulary reflecting associative realities: vegetative, animalistic symbols, color symbols, as well as linguistic and folklore, historical and literary-book allusions.

So, V.S. Vinogradov examines and systematizes the stock of lexical units that convey background information and notes that "the proposed and, apparently, incomplete classification of such units irrefutably testifies how deeply they go into the national language and how widely the roots of national culture are branched in it [7. 60]

The most detailed, in our opinion, classification of realities was proposed by $\mathrm{S}$. Vlakhov and S. Florin. [7. 47-54].The general scheme of their classification is as follows:

i. Subject division.

ii. Local division (depending on national and linguistic affiliation)

iii. Time division (in synchronic and diachronic terms, on the basis of "familiarity")

\section{iv. Translation division.}

Let's consider these classifications in more detail:

By subject division, the following are distinguished:

A. Geographic realities. The realities of the group are associated with physical geography, botanical geography, zoogeography, paleogeography, and so on. Include:

- Names of objects of physical geography, including meteorology.

- Names of geographic features associated with human activity.

- $\quad$ Names of endemic species.

The boundaries of geographic realities are extremely unstable, and an individual approach is required to convey each reality in translation.

B. Ethnographic realities - words denoting the concepts of everyday life, material and 
spiritual culture, religion, art, folklore. It is divided into the following subgroups:

1) The realities of everyday life include the following subgroups of realities: food, drinks, clothes (including shoes, hats, etc.), housing, furniture, dishes and other utensils, transport (vehicles and "drivers") and other realities.

2) The realities of labor include the following subgroups of realities: people of labor, tools and labor organization.

3) The realities of art and culture include the following subgroups of realities: music and dance, musical instruments, folklore, various types of art and art objects, performers, customs, rituals, holidays, games, mythology, cults, calendar.

4) Ethnic objects: ethnonyms, nicknames, names of persons at the place of residence.

\section{5) Measures and money.}

\section{B. Socio-political realities include:}

\section{1) Administrative territorial structure:} administrative-territorial units, settlements, details of a settlement (for example, a lane).

2) Organs and authorities: in fact, the authorities, the bearers of power.

3) Social and political life: political activities and figures, patriotic and social movements (and their leaders), social phenomena and movements (and their representatives), ranks, degrees, titles, appeals, institutions, educational institutions and cultural institutions, estates and castes (and their members), class signs and symbols.
4) Military realities: units, weapons, uniforms, military personnel (and commanders).

By local division, one can distinguish:

\section{A. In the plane of one language:}

1. Their realities are mostly the original words of the given language, they are divided into the following subgroups:

a) National realities - they call objects belonging to a given people, a given nation, but alien outside the country;

b) Local - do not belong to the language of the corresponding people, but either to the dialect, its dialect, or to the language of a less significant social group;

c) Micro-realities - realities, the social or territorial basis of which is already even the most narrow-minded: a word can be characteristic of one city or village without losing its peculiarities and, therefore, requiring the same approach when translating.

2. Alien realities are either borrowings or transcribed realities of another language they are divided into the following subgroups:

a) International are realities that appear in the vocabulary of many languages and are included in the corresponding dictionaries and usually retain at the same time the original national coloration;

b) Regional - those that have crossed the borders of one country or spread among several peoples (not necessarily neighboring), usually with a referent, thus being an integral part of the vocabulary of several languages;

\section{Б. In the plane of a pair of languages:}


Realities are considered from the point of view of translation and are divided into:

1. External realities are equally alien to both languages;

2. Internal realities - words belonging to one of a pair of languages, and, therefore, foreign to another;

"It should be noted here that all divisions are conditional, in the sense that often one and the same unit can be attributed to different headings with the same reason." [7.63] III. Time division. Based on the time criterion, all realities can be roughly divided into:

\section{A. Contemporary \\ B. Historical}

\section{CONCLUSION}

Systematizing the experience of foreign linguists, it becomes clear that a single, generally accepted terminological framework for defining or distinguishing reality-words and reality-objects has not yet been formed. From the above we can conclude that wordstruths are a specific and at the same time more complex and ambiguous category of the lexical system of language. Scholars focus on the subject of truth, give different definitions to this concept, note some features of these lexical units, and ignore others, using different things to define them. In defining the concept of reality, we are close to the approach of the Bulgarian linguists S. Vlakhov and S. Florin, who singled out realities as a special category of means of expression. They define realities as words and phrases that name objects, phenomena, objects characteristic of the life, everyday life, culture, social development of one people and unfamiliar or alien to another people, expressing national and (or) temporary flavor, which, as a rule, do not have accurate matches in another language and requiring a special approach.
In our opinion, the most detailed thing is the classification of truths given by the Bulgarian scholars S. Vlakhov and S. Florin, who defined the truths in terms of subject division, local division, time division, and translation. Each of these groups is further subdivided into subgroups that cover a very wide range of concepts. This is what allows the authors of the classification to highlight and identify a large number of truths in a translated language, taking into account thematic, temporal principles, as well as the principle of local division (in the plane of one or more languages).

\section{REFERENCES}

1. Vlakhov S; Florin S. Untranslatable in translation. Moscow: International relations, 1980. - p.5-6

2. Sobolev L.N. Translation from Russian into French / L.N. Sobolev. Moscow: Education, 1952.-p. 281.

3. Akhmanova O.S. Dictionary of linguistic terms / O.S. Akhmanov. Moscow: Soviet Encyclopedia, 1966. p. 381 p.

4. Brief literary encyclopedia : [in 9 volumes] / ch. ed. A.A. Surkov. Moscow: Sov. encycl., 1962-1978. v. 6, p. 227.

5. Krysin L.P. Explanatory Dictionary of Foreign Words. About 25,000 words and phrases. Ed. 2nd, add. Moscow: Russian language. 2000. -p. 654.

6. Komlev N.G. Dictionary of foreign words: [More than 4500 words and expressions]. Moscow: EKSMO, 2006. -p. 498p.

7. Vinogradov V.S. Introduction to translation studies (general and lexical issues) / Vinogradov V.S. Moscow: Publishing house of the Institute of General Secondary Education of the 
Russian Academy of Education, 2001. p. 37.

8. Fedorov A.V. Fundamentals of the General Theory of Translation / A.V. Fedorov. Moscow: Higher school, 1953. - p. 175.

9. Tomakhin G.D. Realities-Americanisms I G.D. Tomakhin. Moscow: Higher school, 1988. - p. 5.

10. Weisburd M.L. Realities as an element of regional studies / M.L. Weissburd // Rus. lang. abroad. 1972. No. 3. - p. 98.

11. Schweitzer $A D$ Translation and linguistics. Moscow: Voenizdat, 1973.p. 250

12. Rossels V.I. On the transfer of the national form in fiction (Notes of the translator). Moscow: 1953. -p. 169

13. Suprun AE Exotic vocabulary. FN, Moscow: 1958, No. 2, -pp. 50-54

14. Barkhudarov L.S. Language and translation / L.S. Barkhudarov. Moscow: International Relations, 1975. - p.95

15. Kretov A. A. Linguistic theory of reality // A. A. Kretov; N. A. Fenenko. Voronezh Bulletin. state un-that. Ser .: Linguistics and intercultural communication. 2013. No. 1. - pp. 7-13.

16. Vereshchagin E.M; Kostomarov V.G. Language and culture. Ed. 2nd. Moscow: Russian language, 1976.-p. 28

17. Untranslatable in translation / S. Vlakhov, S. Florin. Moscow: International Relations, 1980. - pp. 4754.

18. Vasilyeva N.V. A short dictionary of linguistic terms. Moscow: 1995.

19. Vinogradov, V.S. Lexical issues of translation of literary prose. Moscow: Publishing house of Moscow University, 1978. -p. 172.

20. Muravyov V.L. Lexical lacunae. Vladimir. 1980. -p. 97.
21. Revzin I.I, Rosenzweig V. Yu. Fundamentals of General and Machine Translation. Moscow: 1964. -p. 184.

22. Retsker Ya. I. Translation theory and translation practice. Essays on the linguistic theory of translation, additions and comments by D.I. Ermolovich. Moscow: R. Valent. 2004. -p. 240.

23. Tomakhin G.D. Realities in language and culture / G.D. Tomakhin // Foreign languages at school. 1997. No. 3. - p. 13

24. Fedorov A.V. Introduction to translation theory. Moscow: Ed. Lit. to foreign yaz. 1958. - p. 370.

25. Chernov G.V. To the question of the transfer of non-equivalent vocabulary when translating Soviet journalism into English // Scholarly notes 1-st MGPIIYa,

26. V. XVI. Moscow: 1958.-p. 223.

27. Omonov, Q., \& Karimov, N. (2020). Importance of Ancestoral Heritage. The American Journal of Social Science and Education Innovations, 2(09), 196202.

28. http://library.altspu.ru/ecat/?key=RU\A SPA|RETRO|16846

29. https://evestnikmgou.ru/ru/Articles/View/565

30. http://elar.urfu.ru/bitstream/10995/253 44/1/avfn_2013_61.pdf

31. https://cyberleninka.ru/article/n/realiikak-verbalnoe-vyrazheniespetsificheskih-chert-natsionalnyhkultur 